\title{
A morphometric study on the articulating facets of talus in North Indian population
}

\author{
Shavi Garg', M/s Usha Verma², Arpita Suri³ ${ }^{3}$ Kirandeep Kaur Aulakh ${ }^{4}$ \\ ${ }^{1}$ Associate Professor, ${ }^{4}$ Associate Professor, Department of Anatomy, FMHS, SGT University, Budhera (Gurugram), \\ ${ }^{2}$ Assistant Professor, Department of Anatomy, PGIMS, Rohtak, ${ }^{3}$ Assistant Professor, Department of Biochemistry \\ (FMHS), SGT University, Budhera (Gurugram)
}

Background: Morphometry of talus will be helpful for radiologists, orthopaedicians and surgeons for diagnosis and treatment of talar fractures and making bone prosthesis. Aims and Objectives: The purpose of our study is to do a morphometric analysis of talus to facilitate orthopedicians in planning surgeries for subtalar implants and foot prostheses. This will be of great use to forensic anthropologists. Materials and Methods: For the study, 60 dry adult human tali (24 left and 26 right) were obtained from the Department of Anatomy, SGT Medical College, Budhera. The morphometry of talar surfaces was done using a digital caliper accurate to $0.01 \mathrm{~mm}$ and data was recorded. Results: The mean values of medial, central and lateral length on the trochlear surface were $27.0 \mathrm{~cm}, 28.1 \mathrm{~cm}, 27.4 \mathrm{~cm}$ on right side and $29.4 \mathrm{~cm}, 27.0 \mathrm{~cm}, 29.1 \mathrm{~cm}$ on left side. Mean anterior, central and posterior widths on the trochlear surface were $27.6 \mathrm{~cm}, 26.2 \mathrm{~cm}, 21.1 \mathrm{~cm}$ on right side and $27.0 \mathrm{~cm}, 24.0 \mathrm{~cm}$, $23.1 \mathrm{~cm}$ on left side. The mean central height and width on the lateral articular surface was $26.2 \mathrm{~cm}$ and $21.9 \mathrm{~cm}$ on the right side respectively and $23.0 \mathrm{~cm}$ and $16.8 \mathrm{~cm}$ on the left side respectively. The mean central height and central width on the medial articular surface was $13.6 \mathrm{~cm}$ and $25.9 \mathrm{~cm}$ on the right side respectively and $10.8 \mathrm{~cm}$ and $17.9 \mathrm{~cm}$ on the left side respectively. Conclusions: The current study would be helpful as an important tool for reconstruction surgeries of hindfoot deformities and foot reconstruction procedures. Also it would be useful to orthopaedicians to design accurate talus bone prosthesis and talar implants. Morphometry of talus will be of use in objective categorization and race determination for forensic purposes.

Keywords: Talus; Articular surfaces; Morphometric analysis; Implants

\section{INTRODUCTION}

Talus is the key bone that links the leg and foot through the ankle joint. ${ }^{1}$ Though it carries the whole weight of the human body, it has neither tendon nor muscular attachments. $^{2}$

There are three articulating surfaces on the talus. The superior articular or the trochlear surface of talus is concave transversely and convex parasagittally. It is wider in front. The articular surface for medial malleolus on talus is deep anteriorly and is coma shaped. The lateral talar surface is triangular and concave vertically. ${ }^{3}$ The dimensions of these articular surfaces act as a useful in making the ankle implants and also for total ankle replacements. ${ }^{4,5}$

\section{Access this article online}

Website:

http://nepjol.info/index.php/AJMS DOI: 10.3126/ajms.v12i10.37766

E-ISSN: 2091-0576

P-ISSN: 2467-9100

Copyright (c) 2021 Asian Journal of Medical Sciences

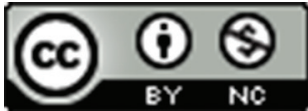

This work is licensed under a Creative Commons Attribution-NonCommercial 4.0 International License.

\section{Address for Correspondence:}

Dr. Shavi Garg, Associate Professor, Department of Anatomy (FMHS), SGT University, Budhera (Gurugram),

Mobile No: +91-9654231458, E-mail: shavigarg6@gmail.com

There is limited data on morphometry of the human tali in North Indian population, and this study will be of use to radiologists, sports therapists and surgeons for diagnosis and treatment of talar neck fractures and in making the talar body prosthesis. This study will be helpful in the treatment of congenital talipes equinovarus (CTEV) or club foot, to identify the degrees of pes cavus and pes planus and also will be of great help to forensic anthropologists. ${ }^{6-8}$

\section{AIMS AND OBJECTIVES}

The purpose of our study is to do a morphometric analysis of talus to facilitate orthopedicians in planning surgeries for subtalar implants and foot prostheses. 


\section{MATERIALS AND METHODS}

The present study was done on 60 dry adult human tali (24 left and 26 right) obtained from Department of Anatomy, SGT Medical College, Budhera. These tali were of unknown gender and age separated into right side and left side. The measurements on the articular facets on the superior, medial and lateral surfaces of body of talus were taken with digital vernier caliper. The following measurements were taken on left and right side:

- Medial, Central and Lateral length on Trochlear surface

- Anterior, Central and Posterior width on Trochlear surface

- Average central height and width on Lateral articular surface

- Average central height and width on Medial articular surface

\section{RESULTS}

On the Trochlear surface, mean values of medial, central and lateral length were $27.0 \mathrm{~cm}, 28.1 \mathrm{~cm}, 27.4 \mathrm{~cm}$ on right side and $29.4 \mathrm{~cm}, 27.0 \mathrm{~cm}, 29.1 \mathrm{~cm}$ on left side (Figure 1). Mean anterior, central and posterior widths were $27.6 \mathrm{~cm}, 26.2 \mathrm{~cm}, 21.1 \mathrm{~cm}$ on right side and $27.0 \mathrm{~cm}, 24.0 \mathrm{~cm}, 23.1 \mathrm{~cm}$ on left side (Table 1).

For the Lateral articular surface: Mean central height on the lateral articular surface was $26.2 \mathrm{~cm}$ on the right side and

\begin{tabular}{|c|c|c|}
\hline Parameters $(\mathrm{cm})$ & Left side & Right side \\
\hline Trochlear Surface & Mean \pm SD & Mean \pm SD \\
\hline Medial length(ml) & $30.18 \pm 3.37$ & $29.87 \pm 2.93$ \\
\hline Central length(cl) & $29.97 \pm 2.11$ & $29.87 \pm 3.14$ \\
\hline Lateral length(II) & $29.60 \pm 1.91$ & $29.32 \pm 2.98$ \\
\hline Anterior width(aw) & $28.16 \pm 2.76$ & $27.01 \pm 2.79$ \\
\hline Central width(cw) & $26.77 \pm 1.94$ & $26.2 \pm 2.76$ \\
\hline Posterior width(pw) & $22.98 \pm 2.46$ & $22.92 \pm 2.33$ \\
\hline
\end{tabular}

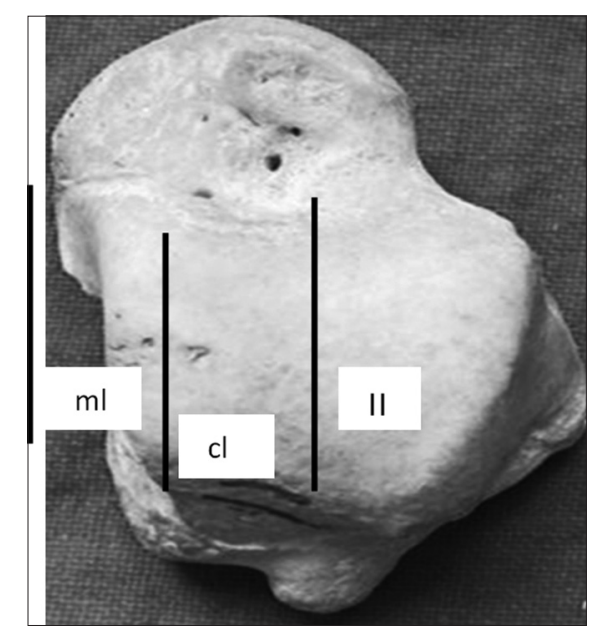

Figure 1: Showing measurement of length of Trochlear surface $(\mathrm{ml}-$ medial length,cl-central length,Il-lateral length)
$23.0 \mathrm{~cm}$ on the left side. Mean central width on the lateral articular surface was $21.9 \mathrm{~cm}$ on the right side and $16.8 \mathrm{~cm}$ on the left side (Table 2 and Figure 2).

For the Medial articular surface: Mean central height on the medial articular surface was $13.6 \mathrm{~cm}$ on the right side and $10.8 \mathrm{~cm}$ on the left side. Mean central width on the medial articular surface was $25.9 \mathrm{~cm}$ on the right side and $17.9 \mathrm{~cm}$ on the left side (Table 2).

\section{DISCUSSION}

This measurement shows that trochlear articular surface is wider in front. The comparison of the measurements taken on the superior articular surface of the body of Talus between right and left tali were almost similar. The parameters are comparable with the study done by Goda Jatin B except for central width of lateral articular surface. Gautham $\mathrm{K}$ found in his study the mean maximum transverse width on the body of Talus was $37.94 \mathrm{~mm}$ on the right side and $36.80 \mathrm{~mm}$ on the left side which was higher compared to present study. Mean Trochlear length was $30.62 \mathrm{~mm}$ on right side and $30.44 \mathrm{~mm}$ on the left side. ${ }^{10}$

Ilhan Otag found that mean values of trochlear length and talar width were $33.45 \mathrm{~mm}$ and $40.79 \mathrm{~mm}$ on right side and $34.12 \mathrm{~mm}$ and $43.39 \mathrm{~mm}$ on left side respectively and these values were observed to be higher than the findings of the present study. ${ }^{11}$

\begin{tabular}{|c|c|c|c|}
\hline & Parameters $(\mathrm{cm})$ & Left side & Right side \\
\hline Lateral & & Mean $\pm S D$ & Mean $\pm S D$ \\
\hline Articular & Central Height (ch) & $24.08 \pm 1.99$ & $23.25 \pm 3.72$ \\
\hline Surface & Central width(cw) & $25.05 \pm 4.3$ & $24.84 \pm 4.08$ \\
\hline Medial & Central Height (ch) & $12.08 \pm 1.58$ & $12.81 \pm 3.66$ \\
\hline $\begin{array}{l}\text { Articular } \\
\text { Surface }\end{array}$ & Central width(cw) & $26.43 \pm 2.75$ & $27.21 \pm 2.56$ \\
\hline
\end{tabular}

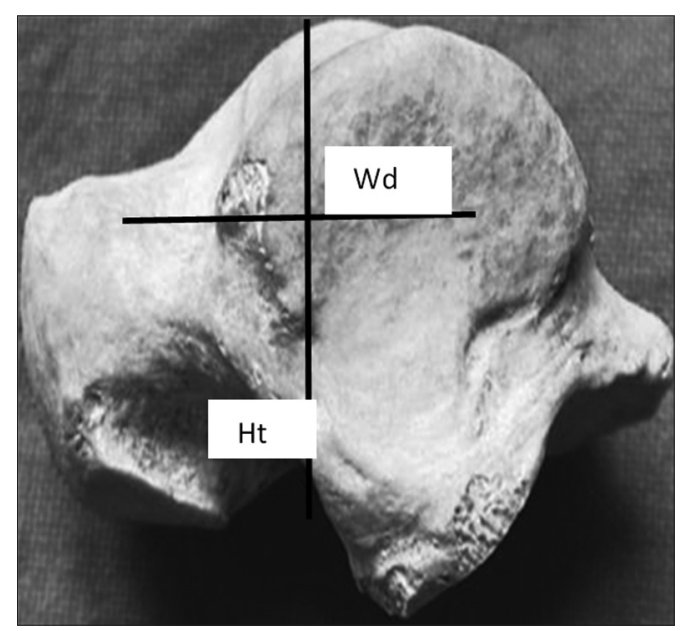

Figure 2: Showing the height $(\mathrm{Ht})$ and width $(\mathrm{Wd})$ of lateral surface

Asian Journal of Medical Sciences | Oct 2021 | Vol 12 | Issue 10 
The measurements done by Berjina Farooq were similar to the present study except for central width of medial and lateral articular surface. ${ }^{12}$

The findings of the present study are similar to the study done by Veenatai $J$ and Janaki $V^{13}$

In the study done by Shishirkumar in South Indian population, the medial length, central length and lateral length of talus was found to be more as compared to the present study. The anterior, central and posterior widths calculated in this study were similar to the present study. ${ }^{14}$

The measurements of anterior and posterior widths done by Roshi Daud et al., in European population were on higher side as compared to the present study. ${ }^{15}$

Also, the anterior, central and posterior widths measured by Andrea Hayer et al., in American population was also on higher side. ${ }^{16}$

The difference in the mean values compared to previous studies may be due to climate, nutrition genetic and environmental factors in the inherent population.

\section{CONCLUSIONS}

The morphometric parameters will be a useful tool for reconstruction surgeries of hind - foot deformities and foot rehabilitation procedures.

The measurements of opposite talus bone can be used as a control during talus bone replacement surgery, it may help surgeons to plan pre-operatively the complex talar fracture surgeries and design talus implants. This study will be of use to forensic anthropologists for age determination, sexual dimorphism, racial differences and stature identification.

\section{REFERENCES}

1. Williams PL, Bannister LH, Berry MM, et al. (Eds.). Gray's Anatomy, $38^{\text {th }}$ edn. Edinburgh: Churchill Livingstone, 1999.

2. Last RJ. Anatomy Regional and Applied, 4th edn. English Language Book Society and J.A. Churchill, Edinburgh, 1970, pp 303-305.

3. Gray's Anatomy. The Anatomical Basis of clinical practice. 40th edition, Elsevier Churchill Livingstone.2008, pp 4279.

4. Motagi MV, Kottapurath SR and Kavitarati D. Morphometric analyses of human dry tali of South Indian origin. International Journal of Medical Sciences and Public Health.2015; 4(2): 237-240. https://doi.org/10.5455/ijmsph.2015.3009201443

5. Khadija I, Sundus A and Shirza N. Anatomical variations of trochlear surface of talus. Journal of University Medical and Dental College.2012; 3(1): 38-41.

6. Ughade HM, Bhele AV and Shaikh S. Morphometric study of human talus - a cross sectional study. International Journal of Anatomy and Research.2017; 5(3.2):4265-4268. https://doi.org/10.16965/ijar.2017.302

7. Peeters K, Schreuer J, Burg F, Behets C, Van Bouwel S, Dereymaeker G, et al. Alterated talar and navicular bone morphology is associated with pes planus deformity: A CT-scan study. Journal of Orthopaedic and Research.2013; 31(2):282-287. https://doi.org/10.1002/jor.22225

8. Yu-Chi Huang. The relationship between the flexible flatfoot and plantar fasciitis: Ultrasonographic evaluation. Chang Gung Medical Journal.2004; 27:443-447.

9. Goda Jatin B, Patel Shailesh M, Parmar Ajay M and Agarwal GC. Morphometry of the Articular Facets on the superior, medial and lateral surfaces of the body of talus and its clinical relevance. International Journal of Medical Research and Health Sciences.2015; 4(3):531-534. https://doi.org/10.5958/2319-5886.2015.00102.2

10. Gautham K, Clarista $M Q$,Sheela $N$ and Vidyashambhava P. Morphometric Analysis of The Human Tali. CIBTech Journal of Surgery.2013; 2(2): 64-68.

11. Otag I and Cimen M. Morphometric measures of talus bone in skeleton remains belonging to Anatolian geography. Indian Journal of Applied Research.2003; 3(8):530-531.

https://doi.org/10.15373/2249555X/AUG2013/168

12. Naqshi BF, Shah $A B$ and Gupta S. Morphometry of articular facets of talus and anatomical variations of the trochlear surface in North Indian population. International Journal of Science and Research. 2018; 7(2):39-40

13. Veenatai J,Janaki V. Morphometry of Articular facets of the body of talus.IOSR-Journal of Dental and Medical Sciences 2017; 16(5):19-21.

https://doi.org/10.9790/0853-1605031921

14. Shishirkumar, Dr. Nambiar S, Dr. Arunachalam Kumar, Dr. Patil GV. Morphometric Analysis of Superior Articulating surface of Talus International Journal of science and research 2014; 3(6): 2387-2391

15. Daud R, Abdul Kadir MR, Izman S, Md Saad AP, Lee MH, Ahmad AC. Three-dimensional morphometric study of the trapezium shape of the trochlea tali. Journal of Foot and Ankle Surgery 2013; 1-6. https://doi.org/10.1053/j.jfas.2013.03.007

16. Hayes A, Tochigi $Y$, Saltzman CL. Ankle morphometry on 3d-ct images. lowa Orthopaedics Journal 2006; 26: 1-4.

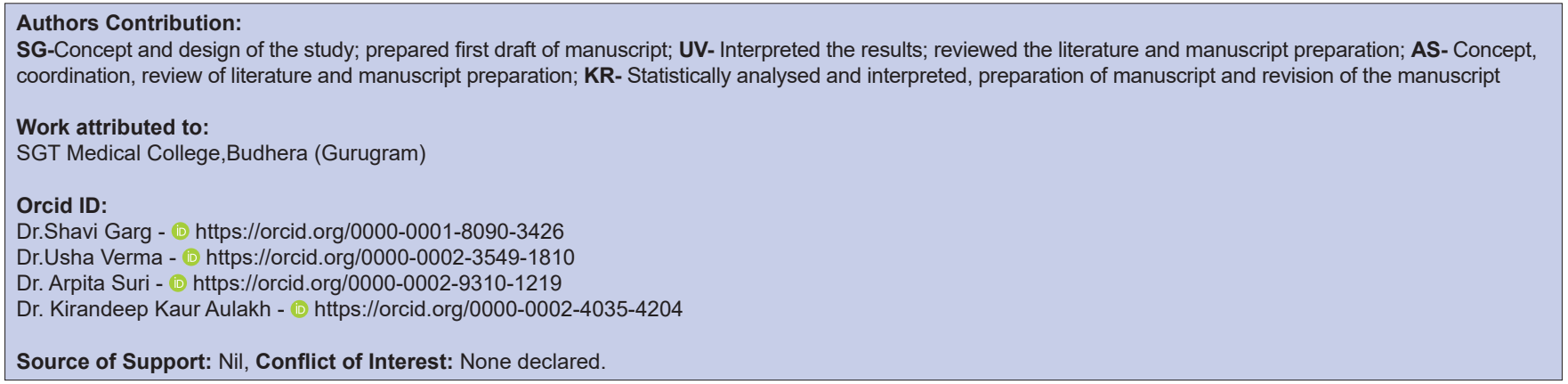

